\title{
INTRODUCTION \\ Opening the Black Box of Migration: Brokers, the Organization of Transnational Mobility and the Changing Political Economy in Asia ${ }^{1}$
}

\author{
Johan Lindquist, Biao Xiang and Brenda S.A. Yeoh
}

\begin{abstract}
This special issue takes the migrant broker as a starting point for investigating contemporary regimes of transnational migration across Asia. The articles, which span large parts of Asia-including China, Indonesia, Laos, Malaysia, Singapore, South Korea, Thailand, Vietnam, as well as New Zealand-show that marriage migration, student migration and various forms of unskilled labour migration, including predominantly male plantation and construction work and female domestic, entertainment and sex work, are all mediated by brokers. Although much is known about why migrants leave home and what happens to them upon arrival, considerably less is known about the forms of infrastructure that condition their mobility. A focus on brokers is one productive way of opening this "black box" of migration research. The articles in this issue are thus not primarily concerned with the experiences of migrants or in mapping migrant networks per se, but rather in considering how mobility is made possible and organized by brokers, most notably in the process of recruitment and documentation. Drawing from this evidence, we argue that in contrast to the social network approach, a focus on the migrant broker offers
\end{abstract}

\footnotetext{
1 This special issue is based on papers presented at the workshop "Opening the Black Box of Migration: Brokers and the Organization of Transnational Mobility," held at the Asia Research Institute at the National University of Singapore, August 19-20, 2010. The workshop was organized by the editors and along with the authors we thank the other paper presenters and discussants: Julie Chu, Dadi Darmadi, Amarjit Kaur, Philip Martin, Rhacel Parreñas, James Sidaway and Per Ståhlberg. Funding was generously provided by the Swedish Foundation for International Cooperation in Research and Higher Education (STINT). Special thanks to the two anonymous reviewers of the introduction and to Hyung Gu Lynn and the staff at Pacific Affairs for their support.
} 
a critical methodological vantage point from which to consider the shifting logic of contemporary migration across Asia. In particular, paying ethnographic attention to brokers illuminates the broader infrastructure that makes mobility possible while revealing that distinctions between state and market, between formal and informal, and between altruistic and profit-oriented networks are impossible to sustain in practice.

KEYWORDS: Migration, brokers, globalization, Asia, methodology

DOI: http://dx.doi.org/10.5509/20128517

$\mathrm{T}$

his special issue takes the migrant broker or middleman as a starting point for investigating transnational migration across Asia. We use the terms "broker" and "middleman" synonymously to denote a party who mediates between other parties, in this case the migrant and the employer or client. Who these brokers are and how they work vary widely. While some are intimately connected to the state, others are closer to the migrants. In fact, brokers may be either state officials or migrants themselves, thus highlighting the uneasy distinctions between state and market, formal and informal, regular and irregular. While some work alone, most are engaged in complicated networks and embody varying forms of expertise. While most are men, with the feminization of migration across Asia an increasing number appear to be women. While some are professional brokers, others are dilettantes (see Molland's article in this issue)_amateurs who become involved in recruitment by accident or as an effect of their social position. As such, a broker is not a fixed identity and must be considered in relation to location, time and power. ${ }^{2}$

The articles in this special issue span large parts of Asia-including China, Indonesia, Laos, Malaysia, the Philippines, Singapore, South Korea, Thailand, Vietnam, as well as New Zealand-where we in particular have noted a dramatic growth in the number of private recruitment agencies that operate as brokers at the centre of a new regime of transnational migration. ${ }^{3}$ The articles show how marriage migration, student migration and various forms of unskilled labour migration-including predominantly male plantation and construction work and female domestic and sex work-are all mediated by brokers.

Although much is known about why migrants leave home and what happens to them upon arrival, considerably less is known about the

\footnotetext{
2 Jeremy Boissevain, Friends of Friends: Networks, Manipulators and Coalitions (Basil Blackwell, 1974), 154.

See, for instance, Johan Lindquist, "Labour Recruitment, Circuits of Capital, and Gendered Mobility: Reconceptualizing the Indonesian Migration Industry," Pacific Affairs 83, no. 1 (2010): 115-132.
} 
forms of infrastructure that facilitate their mobility. By infrastructure we mean the institutions, networks and people that move migrants from one point to another. ${ }^{4}$ This is what we identify as the "black box" in migration research. Black box is a term used within science and technology studies that refers to a system that is viewed primarily in terms of its input and output characteristics. ${ }^{5}$ In other words, the "box" itself is generally not scrutinized in this process, but rather taken for granted. A focus on brokers, we argue, is one productive way of opening the black box of migration research.

In particular, it is important to contrast our focus on brokers with the influential and voluminous literature on migrant networks. Most generally, this literature has been important in critiquing both micro and macro approaches to migration while introducing a multi-level and relational analysis. This perspective positions migrants in a world of constraint and possibility, thus focussing attention on connections across time and space, both within and across national borders. Important parts of this literature have highlighted ethnic and family networksin particular, the social capital and other forms of resources that these embody — as well as the prominence of transnational linkages. ${ }^{6}$

Although there are certainly points of overlap, this special issue sets itself apart from research on migrant networks in several inter-related ways. First, there is a shift of perspective. By focusing on those who move migrants rather than the migrants themselves it is possible to more effectively conceptualize the broader infrastructure that makes mobility possible. Second, this becomes particularly important as we note a historical shift across Asia in which a government-regulated market of circular migration is developing, which in principle can be understood independently of migrant networks. As such, taking the broker as a starting point offers the possibility of conceptualizing this new regime of migration more effectively than through a focus on migrant networks. Third, through an ethnographic approach, the enduring distinction between altruistic social networks and profit-oriented brokers is problematized. In fact, profit, trust and empathy run hand-in-hand in the relationships between brokers and migrants, and distinctions between them are often impossible to sustain in practice. Fourth, the

\footnotetext{
4 This is arguably a somewhat broader term than "migration industry;" see Jon Goss and Bruce Lindquist, "Conceptualizing International Labour Migration: A Structuration Perspective," International Migration Review 29, no. 2 (1995): 317-351.

$5 \quad$ Sergio Sismondo, "Controversies," in An Introduction to Science and Technology Studies (Wiley-Blackwell, 2010).

For an extensive review of the literature on migrant networks, see Steven J. Gold, "Migrant Networks: A Summary and Critique of Relational Approaches to International Migration," in Mary Romero and Eric Margolis, eds., The Blackwell Companion to Social Inequalities (Blackwell, 2005): 257-285.
} 
focus on brokers offers a strategic and more specific methodological starting point for conceptualizing migration compared with the far broader network approach. ${ }^{7}$ This does not mean, however, that the two perspectives cannot be combined, since brokers are often part of multiple networks. A focus on brokers could thus be used to strengthen discussions concerning migrant networks.

But this will not be our task here. In engaging with brokers, we are not primarily concerned with the experiences of migrants or in mapping particular forms of migrant networks per se, but rather in considering how mobility is made possible and organized, most notably in the recruitment process. This is a response to methodological biases that have long been evident in the study of migration, namely the neglect of the infrastructure of migration, which is an "artefact of methodologies" that has focused on migrants, their families and communities, rather than entrepreneurs and brokers. ${ }^{8}$ Underlying this methodological bias is an epistemological framework that has dominated migration research. As Adam McKeown points out in this issue, migration controls that began to take shape at the end of the nineteenth century-concerned with the regulation of borders and migrant identity, rather than routes and modes of transportation-led to a new social science that took the nation-state as a starting point for considering the effects of migration. In other words, the primary function of this new science was to identify the migrants most suitable for the development of the nation in biological, economic and political terms. Indeed, this was arguably the precursor to the form of methodological nationalism that developed within migration studies, and which has been convincingly critiqued from a transnational perspective. ${ }^{9}$

As such, this special issue follows the work of scholars who have noted that "movement" has been taken for granted in the anthropological study of globalization and transnationalism, as either poverty "pushes" and economic development "pulls" migrants, or diasporas are understood as imagined transnational communities. ${ }^{10}$ In other words,

\footnotetext{
7 See, for instance, Thomas Faist's defintion of "network" in The Volume and Dynamics of International Migration and Transnational Social Spaces (Oxford University Press, 2000), 51-52.

$8 \quad$ See Graeme Hugo, "International Migration in the Asia-Pacific Region: Emerging Trends and Issues," in D.S. Massey and J.E. Taylor, eds., International Migration: Prospects and Policies in a Global Market (Oxford University Press, 2004), 78, 94; Douglas Massey, Joaquin Arango, Graeme Hugo, Ali Kouaouci, Adela Pellegrino and J. Edward Taylor, Worlds in Motion: Understanding International Migration at the End of the Millennium (Clarendon Press, 1998), 190; Lindquist this issue.

Andreas Wimmer and Nina Glick Schiller, "Methodological Nationalism and Beyond: Nation-State Building, Migration and the Social Sciences," Global Networks 2, no. 4 (2002), 301-334. See also, Tim Bunnell, "Routes of Identity: Malay Liverpool and the Limits of Transnationalism," Pacific Affairs 83, no. 3 (2010), 459-480.

$10 \quad$ For instance, see the introduction as well as articles by Tom Boellstorff and Anna Tsing in Jonathan Xavier Inda and Renato Rosaldo, eds., The Anthropology of Globalization: A Reader (Wiley-Blackwell, 2008).
} 
the infrastructure of movement has not been sufficiently considered in empirical or analytical terms. Following this lead, we argue that the middle space of migration ${ }^{11}$ — that of brokers and recruitmentis an ideal methodological vantage point from which to consider transnational migration systematically. In particular, Xiang's use of the term "transplant" rather than "flow" in describing contemporary transnational migration poignantly highlights our shift of attention away from the migrant towards a system or set of actors that move migrants. ${ }^{12}$

\section{Shifting Regimes of Transnational Migration in Asia}

Our focus on brokers follows from a striking empirical observation. In stark contrast to widespread fears that unauthorized migration is an unstoppable force, during the last decade there has been an increasing formalization of migration management, often precisely at the expense of unauthorized migration. Such formalization is taking shape in the context of the centralization of migration control and the fragmentation of labour management, as well as the "upward" concentration of capital and the "downward" outsourcing of labour. ${ }^{13}$ As state and private actors attempt to both protect migrants, most often with regard to nationalist and universalist human rights discourses, and regulate their mobility, generally through bilateral agreements and contracts that transform migrants into temporary guestworkers, the market for recruitment has become increasingly decentralized. In this ongoing process, brokers increasingly come to mediate flows of capital, information, facilitate bureaucratic process, and move the migrants themselves. ${ }^{14}$ This is evident not only in the context of unskilled labour but also in the expanding market for student and marriage migration (see the articles by Collins and Chee, Yeoh and $\mathrm{Vu}$, respectively, in this issue), as hierarchies of regulation are increasingly being developed that treat migrants differently depending on ethnicity or level of education and skills. But

\footnotetext{
11 Middle space recalls the term "middle passage" - a metaphor for the Atlantic slave trade-which, as McKeown notes in his article in this issue, illustrates the importance of infrastructure and brokers in the migration process, more generally.

12 Xiang Biao, "Transplanting Labour in East Asia," in Yamashita Shinji, Makito Minami, David Haines and Jeremy Edes, eds., Transnational Migration in East Asia: Japan in a Comparative Focus (Osaka: National Museum of Ethnology, Senri Ethnological Reports 77, 2008), 175. See also Alan and Josephine Smart, who propose an alternative metaphor, "punctuation," in order to reconceptualize migrant flows and stoppages at the border to Hong Kong. "TimeSpace Punctuation: Hong Kong's Border Regime and Limits on Mobility," Pacific Affairs 81, no. 2 (2008): 175-193.

13 Xiang, "Transplanting Labour."

14 For examples from the Philippines, see Robyn Rodriquez, Migrants for Export: How the Philippine State Brokers Labor to the World (Minneapolis: University of Minnesota Press, 2010); and Anna Guevarra, Marketing Dreams, Manufacturing Heroes: The Transnational Labor Brokering of Filipino Workers (Rutgers University Press, 2010).
} 
precisely because migration management is becoming increasingly sophisticated, the demand for brokers is omnipresent on all levels.

An important manifestation of such formalization in the era of neoliberalism is that "circular migration" has moved to the top of the international policy agenda as the management form of the future. ${ }^{15}$ Documented circular migration has come to be considered a "win-winwin situation," as receiving countries are guaranteed labour, sending countries create stable remittance systems for development, and migrants gain access to secure employment. ${ }^{16}$ The turn to circular migration is arguably part of a trend in which the dual concern with regulation and protection of migrant mobility is at the centre of attention, as Molland's article in this issue shows. More broadly, this should be understood as a response to widespread concerns about the control of national borders, as well as the prevalence of transnational migration characterized by informality, illegality and abuse.

In regulated systems of circular migration organized by states and markets-as opposed to unregulated systems created through networks of migrants themselves - the migrant is ideally transferred from the sending country to the receiving country and back again on timelimited contracts. This trend is particularly obvious within the AsiaPacific migration system, where governments have tended to promote and regulate international migration as an export market for national development, ${ }^{17}$ most evidently in the Philippines and Indonesia, but also increasingly so in China. In fact, Xiang argues forcefully that the rise of regulated return migration signals the reinforcement of the sovereignty of the nation-state. ${ }^{18}$

More generally, the fragmentation of migrant management and the centralization of state control signals a changing relationship between states, markets and migrants. These changes are often considered in relation to the dual process of "rolling back" and "rolling out" of the state that theorists of neoliberalism (or neoliberalization) have highlighted in the past decade, in which the deregulation of markets has been matched

\footnotetext{
15 Steven Vertovec, "Circular Migration: The Way Forward in Global Policy?" International Migration Institute (IM) Working Papers(2007), http://www.imi.ox.ac. uk/pdfs/imi-working-papers/wp4-circular-migration-policy.pdf, accessed January 31, 2011; Graeme Hugo, "Best Practices in Temporary Labour Migration for Development: A Perspective from Asia and the Pacific," International Migration 47, no. 5 (2009): 23-74; Alejandro Portes, "The Fence to Nowhere: More than ever, we need to craft an accord on migrant workers," The American Prospect (October, 2007), 26-29.

${ }_{16} \quad$ Vertovec, "Circular Migration," 2.

17 Jon Goss and Bruce Lindquist, "Placing Movers: An Overview of the Asian-Pacific Migration System," The Contemporary Pacific 12, no. 2 (2000), 394.

18 See Xiang Biao, "Introduction," in Return: Nationalizing Transnational Mobility in Asia, eds. Xiang Biao, Brenda Yeoh and Mika Toyota (Durham: Duke University Press, forthcoming).
} 
by renewed state intervention. ${ }^{19}$ While we find this research important, it generally offers limited guidance in understanding the varying roles that brokers play in different settings across Asia, where the state remains a powerful organizing force for transnational migration. Instead, we build primarily upon what might be called the "governmentality" or "statecraft" school, which examines how migration becomes a concern and subject for governance, and how the state devises a wide range of practices-institutional, discursive and tactical—to regulate mobility; and, conversely, how state power is constituted or challenged in this process..$^{20}$ Although the state remains the analytical centre of attention in much of this literature, it is not the only or necessarily even the primary site of power as the market or citizens themselves take on tasks historically associated with the state. ${ }^{21}$ For instance, in his article in this issue, Xiang claims that broker networks should not be understood as external to state power, but rather as integral to new forms of governance and governmentality in the context of the neoliberalizing Chinese state. More generally, this special issue shows that disciplinary power is not evenly diffused but rather specifically concentrated in the interfaces where brokers are positioned. This approach thus deepens our understanding of the increasingly complex and evolving processes of mediation between the state, market and migrants.

\section{Relocating Brokers}

Despite their deep entanglement in migration management, formal brokers are, much like informal smugglers and traffickers, generally demonized by academic researchers, nongovernmental organizations and policymakers alike in debates concerning the regulation of transnational migration. According to the Global Commission of International Migration, for instance, private recruitment agencies increase costs and distort markets, while infringing on state sovereignty

\footnotetext{
19 See Jamie Peck and Adam Tickell, "Neoliberalizing Space," Antipode 34, no. 3 (2002): 380-404.

20 For examples of the Foucaultian "governmentality" literature, see Liisa Malkki, "Refugees and Exile: From 'Refugee Studies' to the National Order of Things," Annual Review of Anthropology 24 (1995): 495-523; John C. Torpey, The Invention of the Passport: Surveillance, Citizenship, and the State (Cambridge University Press, 2000); Thomas Blom Hansen and Finn Stepputat, eds., Sovereign Bodies: Citizens, Migrants, and States in the Postcolonial World (Princeton University Press, 2005); and Rodriquez, Migrants for Export. The most influential scholar who focuses on "statecraft" is James Scott, Seeing Like a State: How Certain Schemes to Improve the Human Condition Have Failed (Yale University Press, 1998) and The Art of Not Being Governed: An Anarchist History of Upland Southeast Asia (Yale University Press, 2009).

21 See, for instance, Nikolas Rose, Powers of Freedom: Reframing Political Thought (Cambridge University Press, 1999).
} 
and individual rights. ${ }^{22}$ This follows from the classic stereotype of the broker as a streetwise thug who works outside the law, luring innocent migrants into exploitative situations, the most notable contemporary example being the trafficker of women and children into prostitution. The rise in a global interest in human trafficking, in particular, has reinforced a dichotomy between "victim" and "perpetrator," not only through discourse but also in terms of the resources that are allocated by international agencies and governments in the struggle against migrant exploitation. In this process, there is great concern with caring for victims, while the brokers themselves continue to be taken for granted..$^{23}$ This does not mean that we deny that brokers often engage in exploitative practices, merely that this should be an empirical question and not one that is answered a priori. As such, the specific question of migrant exploitation and the broader question of ethics should be considered systematically across a wide range of practices, rather than through a strict focus on brokerage.

While the starting point of this special issue is the observation that there has been an increase in formally licensed private recruitment agencies across Asia, it is clear that the relationship between formal and informal brokers should be understood as a continuum rather than a dichotomy. Lindquist's article, for instance, shows clearly how formal agencies depend on unlicensed informal brokers with social connections to the villages that are the key sources of migrant labour in Indonesia. In the article in this issue on the international marriage market in Malaysia (Chee et al.), some marriage migrants draw on social networks to become commercial matchmakers themselves in an expanding but highly fluid market. In other words, a focus on the recruitment of transnational migrants inevitably problematizes distinctions between licensed and unlicensed, between legality and illegality, and even between the migrant and broker which, in turn, points to the importance of resisting the a priori vilification of brokers.

Although it is clearly the case, as Philip Martin has noted, that migrants themselves are increasingly carrying the burdens of added costs, particularly in Asia, ${ }^{24}$ it is also obvious that brokers cannot be blamed across the board since they result from complex institutional arrangements and play multiple roles. In fact, increasing government

\footnotetext{
22 Global Commission of International Migration, Migration in an Interconnected World: New Directions for Action (Geneva: Global Commission of Internationl Migration, 2005), 70.

23 Jo Doezema, Sex Slaves and Discourse Masters: The Construction of Trafficking (Zed Books, 2010).

24 Philip Martin, "Merchants of Labor: Labor Recruiters in Asia," paper presented at the workshop, "Opening the Black Box of Migration: Brokers and the Organization of Transnational Mobility," Asia Research Institute, National University of Singapore, August 19-20, 2010.
} 
regulations are creating intricate systems of paperwork that are navigated by experts in small-scale bureaucracy, and thus raising costs. This suggests that there should be caution in celebrating new regimes of circular migration without carefully considering how they are played out in empirical terms. In this issue, for instance, McKeown states the point clearly: "Just as anti-trafficking programs obscure the role of employers by shining the light of criminality on brokers, so guest workers obscure the role of brokers behind the brilliant glare of laws and employer regulation." In other words, guest worker programs such as those celebrated in the new regime of circular migration and the shadowy world of trafficking should be considered together, not only through the figure of the broker, but also because both exist in a world of inequality in which unskilled migrants have limited choices.

McKeown's wide-ranging historical account in this issue effectively creates a historical frame for discussion by illuminating the origins of the dichotomy between the "free" and "unfree" migrant that emerged with the rise of liberalism and in the wake of the abolitionist movement in Europe and North America, and has been reinforced since. Significantly, in this process another dichotomy developed between trans-Atlantic mobility as largely free and inherently modern in its aspiration and Asian migration as dictated by unscrupulous brokers and characterized by premodern social forms. Public debate and journalism added much to the demonization of brokers and the exaggerated importance of indenture. At the same time, it was precisely these stereotypes of impenetrable Asian cultures that made brokers appear indispensible to employers. By the 1920s, immigration regulations based on passport controls at national borders had become a standardized global regime, and brokers were no longer allowed to function as formal mediators. Although this made brokers increasingly illicit, the focus on paperwork and process created further opportunities, as employers found it easier to delegate regulatory tasks to brokers rather than dealing with individual workers directly. A further consequence of this is the production of a boundary between "legality" and "illegality" that in practice has become a distinction between those migrants who have their "papers in order," and those who do not.

With this history in mind, the articles in this special issue problematize the general process of stereotyping brokers. Rather than placing blame squarely on brokers this perspective allows us to initiate more complicated discussions concerning ethics and liability in transnational migration. Through detailed empirical work, the articles develop a comparative perspective on migration brokers across Asia. While our existing research indicates that migration brokerage is nearly universal-and often transnational or even global in operation-it is at the same time highly local, as the patterns of operation are specific to local societies, particular occupations, or recruited populations. Furthermore, like movement 
more generally, the contemporary infrastructure of migration is difficult to grasp largely because it cannot be distinguished from shifting forms of political economy. In other words, the infrastructure of migration is by no means autonomous but is rather structured according to the uneven political, economic and social systems that it traverses, thus often disturbing any easy distinctions between state and private actors. Brokers are located at the intersections of these actors and systems.

Finally, it is important to note that brokers are always located in the gendered landscape of migration. In the wake of the feminization of migration across Asia, brokerage is both increasingly gendering and gendered. Several articles in this special issue highlight the recruitment of women into marriage migration, domestic service and sex work (see the articles by Chee et al., Lindquist and Molland, respectively), and the broad moral anxieties this generates, particularly in relation to discourses concerning human trafficking. It is therefore not surprising that our research shows that a large number of migration brokers are women, even if men still appear to be predominant. Importantly, gender often structures the forms brokerage takes, as migrant debt, labour rights and visa processes often vary between men and women, particularly with the increasing formalization of migration.

\section{Introducing the Articles}

As has already been noted, Adam McKeown's historical article describes the transformation of the role and perceptions of the migrant broker after the rise of liberalism, and offers a model for understanding how the broker has been black-boxed in academic, political and public discourse. His point, in fact, is that any understanding of Asian migration brokerage must be understood as emerging in a global historical context. The following article by Xiang considers the changing forms of migrant recruitment in China since the era of liberalization. Based on extensive field research, Xiang describes the shift from a limited number of stateowned monopolies, so-called "window companies," to the much larger number of private agencies that have been licensed during the era of liberalization. More generally, Xiang notes the intertwining of liberal and interventionist approaches adopted by the Chinese government in dealing with brokers, the former through deregulation and the latter by means of tightening regulations. In this process, the Chinese government has put in place measures to protect migrants from agents-women in particular are sites of moral anxiety and concern-while deregulating the market for recruitment. Most notably, Xiang understands the rise of recruitment agencies, not as a sign of the incomplete centralization of state power, but rather as a product of hypercentralization in which the government allows broker networks a particular form of autonomy while 
holding them by the "neck," thus governing transnational movements of labour without knowing the details of mobility. As Xiang succinctly phrases it: "How agents make money is how the state makes order."

In contrast to Xiang, Lindquist's article focuses attention on the informal brokers who mediate between private recruitment agencies, government authorities and villagers who become migrants on the Indonesian island of Lombok, a key sending area for male migrants to palm oil plantations in Malaysia and women who work as domestic servants across Asia and the Middle East. As in China, there has been a dramatic growth in private recruitment agencies since the market was deregulated following the 1997 Asian economic crisis and the fall of President Suharto. But while private recruitment agencies are licensed, it is a wide array of informal brokers who actually recruit migrants. In contrast to Xiang's account, which highlights the enduring power of the state, Lindquist's micro-sociological perspective reveals the importance of broker performativity and migrants' trust towards brokers in the recruitment process. Through this difference of perspective, the articles reveal the complexities of migration management and how brokerage emerges on various levels.

In their article on marriage brokers between Malaysian men and Vietnamese women, Chee et al. make the important point that all types of marriage brokers, be they formal agencies or informal actors, must use social networks and referrals to gain access to male clients in Malaysia. ${ }^{25}$ In this way, brokers efficiently expand both their social networks and market each time they make a successful match. The Vietnamesewife-turned-successful broker is a case in point, which illuminates that brokering is often temporary and does not necessarily lead to a sustainable career. Brokerage thus becomes self-perpetuating and ever-expanding through the constant involvement of new brokers, yet remains unstable and unpredictable as the specific actors are always changing. As in the case of labour recruitment in Indonesia, trust appears to be of critical importance in the process of match-making, thus highlighting a theme that cuts through this issue: altruistic and profit-oriented social networks cannot be disentangled from one other.

In his article on anti-trafficking programs along the Lao-Thai border, Molland makes a similar point when he claims that many brokers work within social networks, and that much of this brokering is ad hoc and based on opportunity. He terms these dilettante brokers. This is in contrast to anti-trafficking programs that assume that migration brokers are generally external to the migrants' social environment, in contrast to

25 For a particularly striking case of the rise of marriage migration in Taiwan, see Sara Friedman, "Marital Immigration and Graduated Citizenship: Post-Naturalization Restrictions on Mainland Chinese Spouses in Taiwan," Pacific Affairs 83, no. 1 (2010): 73-93. 
the more intimate social networks of friends and relatives. Much in line with the turn to circular migration described above, legalizing migration and creating channels of "safe migration" is understood by international organizations such as the United Nations Development Program as a win-win situation that creates stable markets for wage labour, which in turn may become a source of local development in Laos. But as Molland points out, this is based on the assumption that the promotion of documented migration will dry out the market for trafficking. In fact, he argues the opposite may be the case as high costs associated with documented migration increases the likelihood of debt-bondage. Of further note is the remarkable increase in anti-trafficking programs in Laos and across Asia, which parallels the rise of private recruitment agencies during the last decade. Following McKeown's comparison of trafficking and guest worker programs, there is much to be considered in the relationship between the protection and regulation of migrants in the current era.

Collins' article on education brokers and student migration from South Korea to New Zealand situates the commercialization of the education sector in New Zealand (and indeed around the world) in the context of neoliberal reforms, which has led to intensifying attempts to attract overseas students. In contrast to the other articles in this issue, he focuses on a relatively privileged group of migrants who will most likely become white-collar workers. In describing the education brokers that are at the heart of this industry, however, Collins highlights the same false dichotomy that other authors note between profit-oriented industry and altruistic social networks. For instance, brokers depend on personal networks and have often been students themselves. They offer personal services, picking up and dropping off at the airport, providing temporary accommodation, rebated phone cards and Internet access. It is the very ability to bridge the divide between profit and social relations, Collins argues, that makes the education broker a critical player in relation to students, education providers and the state. At the same time, there are familiar concerns with brokers' abusive practices, as the New Zealand government has responded by focusing attention on and attempting to regulate the ethical performance of brokers.

In conclusion, this special issue argues that a comparative study of migrant broker systems promises to shed important light on how globalization is both embedded in and transcends particular sites. In other words, we argue that a focus on brokers will allow us to describe how people in different locations develop social relations at different scales that contribute to economic globalization, rather than vice versa. More generally, the apparent rise of brokers working on a transnational scale runs against the grain of much existing research. For example, most economists hold that brokers exist because they have the function 
of bridging the information gap between demand and supply, and that once the gap narrows, the agents should disappear to minimize transaction costs. In similar terms, mainstream approaches in migration studies suggest that agents are eventually replaced by migrant networks. Governments and nongovernmental organizations often blame agents for abusing migrant rights and contributing to policy failures, and have tried hard to regulate or eradicate them, while information technology (IT) is expected to lead to a process of "disintermediation." In reality, however, business seems to be as good as ever, and IT has facilitated the proliferation instead of the elimination of intermediaries such as headhunters, law firms and consultants, while intensifying the government regulation of migrant mobility has had similar effects. A comparative, bottom-up understanding of migrant brokers in Asia thus challenges conventional wisdoms and sheds new light on the hidden organizational logic not only of transnational migration, but also of the current phase of globalization.

Stockholm University, Stockholm, Sweden; Oxford University, Oxford, United Kingdom;

National University of Singapore, Kent Ridge, Singapore, November 2011 